\title{
Abortive phage-infection and UV-protection markers on Col I plasmids from epidemic strains of Salmonella
}

\author{
RUTH M. BARKER
}

Department of Microbiology, University of Dundee Medical School, Ninewells Hospital, Dundee DD1 9SY

\begin{abstract}
Summary. Cultures of Escherichia coli carrying Coll plasmids received in conjugation from strains of Salmonella typhimurium and $S$. agona were examined for abortive infection (Abi) of phage BF23 and for enhanced resistance to the lethal action of UVirradiation (Uvr). The Abi character of stored cultures of $E$. coli was also compared with the reaction of the same stock culture tested 5 years before. Seven of the eight potential types differentiated by three characters were represented among 160 ColI plasmids: Colla $\mathrm{Abi}^{+} \mathrm{Uvr}^{+}$(3 plasmids), ColIa $\mathrm{Abi}^{-} \mathrm{Uvr}^{+}$(1), ColIa $\mathrm{Abi}^{-} \mathrm{Uvr}^{-}$ (2), Collb Abi ${ }^{+} \mathrm{Uvr}^{+}$(85), Collb Abi ${ }^{+} \mathrm{Uvr}^{-}$(5), Collb Abi ${ }^{-} \mathrm{Uvr}^{+}$(4), Collb Abi ${ }^{-}$ $\mathrm{Uvr}^{-}$(60). Recognition that different plasmid types could be carried by strains of a clone proved useful in the interpretation of the epidemic spread of strains of $S$. typhimurium of phage type/biotype 141/9f in Scotland and in tracing the ancestry of a recently emerged rhamnose non-fermenting mutant strain of S. agona.
\end{abstract}

\section{Introduction}

Epidemiological investigations of salmonella infections require accurate strain identification, and phage typing is the method of first choice for differentiating epidemic strains. The discriminating power of phage typing, however, may be greatly enhanced when it is used in conjunction with a second method such as biotyping (Anderson et al., 1978). In many cases epidemic strains of the same phage type and biotype are probably clonal in origin (Barker, 1986a). During epidemic spread clonal strains sometimes acquire additional plasmids that may serve to differentiate subtypes within the clone.

Although colicinogeny is one such acquired character that can be determined easily, colicin production has been considered of little value as a primary typing method because most serotypes of Salmonella produce a limited range of colicins (Barker, 1980). ColI is the most common colicin plasmid found in Salmonella and consideration of other characters sometimes associated with ColI has extended the number of types recognised. The plasmids may be identified by immunity pattern as subtype ColIa or ColIb (Stocker, 1966) and both subtypes may be further differentiated by the character of abortive phage infection (Strobel and Nomura, 1966; Yousuf et al., 1987). In addition, some Coll plasmids carry genes conferring on the

Received 8 June 1987; accepted 15 June 1987 host bacterium resistance to UV irradiation (Howarth, 1965). These additional marker characters of abortive infection (Abi) and UV-protection (Uvr) differentiated epidemic Collb ${ }^{+}$strains of $S$. agona isolated in Dundee in 1979 and 1980 (Barker, $1986 b$ ).

The experiments reported in this paper describe the stability of the Abi character and the UVprotection character of 160 Coll plasmids of known colicin type. The Col plasmids from strains of $S$. typhimurium and $S$. agona have been assigned colicin, Abi and Uvr types. The value of this greater degree of differentiation of plasmid types is demonstrated with reference to epidemic strains of $S$. typhimurium and $S$. agona of known phage type (PT) and biotype (BT).

\section{Materials and methods}

\section{Bacterial strains}

The phage type and biotype of the 132 colicin Iproducing strains of $S$. typhimurium and of 28 strains of $S$. agona are given in table I.

Shigella sonnei strain CT4 of Abbott and Shannon (1958) carried ColIb-P9. E. coli strain K12 14R519, Fand $\mathrm{Nal}^{\mathrm{R}}$ (Anderson, 1975) was used as the recipient of ColI plasmids in conjugation experiments. Stock cultures were maintained at ambient temperature on Dorset's egg medium in screw-capped bottles, some cultures of Salmonella for as long as 25 years and some of the recipient cultures of $E$. coli for as long as 5 years. 
Coll was transferred from the producing culture of Salmonella to $E$. coli strain 14R519 during overnight mixed culture in static conditions in Nutrient Broth (Oxoid) at $37^{\circ} \mathrm{C}$. Colonies of E. coli were selected on Nutrient Agar (Oxoid) containing nalidixic acid (40 $\mu \mathrm{g} / \mathrm{ml}$ ); individual colonies were tested for colicin production by the overlay method of Ozeki et al. (1962).

\section{Bacteriophage and phage restriction}

Bacteriophages BF23 and T5 were supplied, respectively, by Professor B. A. D. Stocker and Professor N. Symonds. They were propagated on E. coli strain K12 14R519.

Phage lysate $\left(10^{10}\right.$ plaque-forming units $\left./ \mathrm{ml}\right)$ was diluted in nutrient broth and titrated on lawns of bacteria on plates of nutrient agar by the method of Males and Stocker (1980).

\section{Source of UV irradiation and test for sensitivity}

The UVC source and details of the method of estimating the exposure time (log. s) giving $50 \%$ killing of the irradiated culture have been described when used in the determination of the Uvr character of ColIb plasmids carried by strains of $S$. agona isolated in Dundee (Barker, 1986b).

\section{Results}

In 160 conjugation experiments the ColI plasmid was transferred from 132 strains of $S$. typhimurium and 28 strains of $S$. agona to cultures of $E$. coli strain 14R519. Colicin production was taken as evidence of carriage of the plasmid. $\mathrm{Col}^{+}$cultures of the recipient lines were examined for abortive infection of phage BF23 within 6 months of transfer of the plasmid (Yousuf et al., 1987). Of the 160 ColI plasmids, 93 expressed the $\mathrm{Abi}^{+}$phenotype (table I).

After an interval of 1-5 years after receipt of the plasmid, $\mathrm{Col}^{+}$cultures of $E$. coli were examined for sensitivity to UV-irradiation. At each dose level of irradiation, i.e., exposure for $0.60,0.95$ and 1.15 $\log$. s, the survival of $E$. coli strain 14R519 without a Col plasmid was considerably less than that of the same line of $E$. coli carrying Collb-P9. The time required for $50 \%$ killing of the $\mathrm{Col}^{-}$line of $E$. coli in 32 replicate tests was $0.69 \mathrm{log}$. s (range $0.55-$ $0 \cdot 80$ ) and of E. coli carrying Collb-P9 in 10 replicate tests was 1.07 log. s (range 1.00-1.11). Recipient strains of $E$. coli carrying ColI plasmids derived from $S$. typhimurium and $S$. agona segregated into 67 that survived exposure to UV to give a time for $50 \%$ killing of $\leqslant 0.8 \mathrm{log}$. s (and similar, therefore, to $E$. coli strain $14 \mathrm{R} 519$ without a Col plasmid, i.e., were $\mathrm{Uvr}^{-}$) and 93 that survived for $\geqslant 0.85 \log$. $\mathrm{s}$ (i.e., were $\mathrm{Uvr}^{+}$). Of the recipient strains carrying Col plasmids expressing the $\mathrm{Uvr}^{+}$phenotype, 43 showed a survival pattern similar to that of $E$. coli strain 14R519 ColIb-P9, for which the time for $50 \%$ killing was $\geqslant 1.0 \mathrm{log}$. $\mathrm{s}$ and 50 survived to give a count resulting in the $50 \%$ killing time falling within the range $0.85-0.99 \mathrm{log}$. s indicating an intermediate level of protection to UV.

When cultures that had been stored for up to 5 years were re-examined for colicin production and abortive infection, 159 produced colicin and 90

Table I. Abortive infection (Abi) and sensitivity to ultraviolet irradiation (Uvr) of E. coli strain 14R519 with ColI plasmids from strains of S. typhimurium and S. agona

\begin{tabular}{|c|c|c|c|c|c|c|c|c|}
\hline \multirow[b]{2}{*}{ Strain* } & \multirow[b]{2}{*}{ Phage type } & \multirow[b]{2}{*}{ Biotype } & \multirow[b]{2}{*}{ Colicin type } & \multirow[b]{2}{*}{$\begin{array}{c}\text { Number } \\
\text { tested }\end{array}$} & \multicolumn{4}{|c|}{ Number with reaction pattern } \\
\hline & & & & & $\begin{array}{l}\mathrm{Abi}^{+} \\
\mathrm{Uvr}^{+}\end{array}$ & $\begin{array}{l}\mathrm{Abi}^{+} \\
\mathrm{Uvr}^{-}\end{array}$ & $\begin{array}{l}\mathrm{Abi}^{-} \\
\mathrm{Uvr}^{+}\end{array}$ & $\begin{array}{l}\mathrm{Abi}^{-} \\
\mathrm{Uvr}^{-}\end{array}$ \\
\hline S. typhimurium & 135 & $25 \mathrm{~h}$ & $\mathrm{Ib}$ & 6 & 0 & 0 & 0 & 6 \\
\hline S. typhimurium & 141 & 1f & $\mathrm{Ib}$ & 5 & 5 & 0 & 0 & 0 \\
\hline S. typhimurium & 143 & $17 \mathrm{a}$ & $\mathrm{Ib}$ & 41 & 40 & 1 & 0 & 0 \\
\hline S. typhimurium & 56 & $17 \mathrm{~g}$ & Ia & 3 & 2 & 0 & 0 & 1 \\
\hline S. typhimurium & 56 & $17 \mathrm{~g}$ & Ib & 13 & 5 & 0 & 0 & 8 \\
\hline S. typhimurium & 141 & $9 f$ & Ia & 3 & 1 & 0 & 1 & 1 \\
\hline S. typhimurium & 141 & $9 f$ & Ib & 61 & 11 & 4 & 0 & 46 \\
\hline S. agona & $\mathrm{I}$ or $\mathrm{V}$ & la & Ib & 8 & 4 & 0 & 4 & 0 \\
\hline S. agona & XVI & $5 a$ & $\mathrm{Ib}$ & 20 & 20 & 0 & 0 & 0 \\
\hline
\end{tabular}

\footnotetext{
* Strains of $S$. typhimurium of known PT/BT were: from localised outbreaks 135/25h (Barker et al., 1980), 141/1f (Barker and Old, 1979) and 143/17a (Anderson et al., 1978); or from extended outbreaks 56/17g (Barker et al., 1980 ) and 141/9f (Barker and Old, 1979). Strains of S. agona were from Zaire (Barker et al., 1982).
} 
were $\mathrm{Abi}^{+}$. One culture of $S$. typhimurium of phenotype $\mathrm{Abi}^{+} \mathrm{Uvr}^{+}$when first tested, was $\mathrm{Abi}^{-}$ on retesting, but was still protected against UV (time for $50 \%$ killing of $1.03 \mathrm{log}$. s).

Abi and Uvr character of Coll plasmids from phagetyped and biotyped strains of $S$. typhimurium and $S$. agona

The Coll plasmids from 132 strains of $S$. typhimurium and 28 strains of $S$. agona were assigned an Abi type (by the reaction in the test made on the $E$. coli recipient stock culture when first tested) and a Uvr type. The Abi and Uvr types have been matched with the colicin type, phage type and biotype of each strain of Salmonella (table I).

Among the 41 cultures of E. coli carrying ColIb plasmids that originated in $S$. typhimurium strains of PT/BT $143 / 17 \mathrm{a}, 40$ were $\mathrm{Abi}^{+} \mathrm{Uvr}^{+}$and one was $\mathrm{Abi}^{+} \mathrm{Uvr}^{-}$. Other lines of $E$. coli that received this Col plasmid from the same strain of $S$. typhimurium during independent conjugation experiments were also $\mathrm{Uvr}^{-}$. Independent conjugation experiments with another strain of $S$. typhimurium of PT/BT 143/17a gave rise to cultures of $E$. coli that were $\mathrm{Abi}^{+} \mathrm{Uvr}^{+}, \mathrm{Abi}^{+} \mathrm{Uvr}^{-}$or $\mathrm{Abi}^{-} \mathrm{Uvr}^{+}$. Tests for abortive infection on several colonies of the Collb-recipient line of $E$. coli indicated that the stock culture of $S$. typhimurium harboured plasmids of both $\mathrm{Abi}^{+}$and $\mathrm{Abi}^{-}$ phenotypes.

Details of the colicin type of the ColI plasmids carried by strains of $S$. typhimurium of PT/BT 141/ 9f isolated in Scotland between 1972 and 1977 have been reported (Barker and Old, 1979). The Abi and Uvr characters of these plasmids are given in table I and, with details of each outbreak, in table II. Colicinogeny among strains of $S$. agona was rare except among cultures received from Zaire where patients were infected with $\mathrm{ColIb}^{+}$strains of biotypes 1a and 5a (Barker et al., 1982). The Abi and Uvr characters of the ColIb plasmids carried by these strains of $S$. agona are given in tables I and III. The additional information gained by determining the Abi and Uvr types of these Coll plasmids and its contribution to the epidemiological analysis of the strains are discussed below.

\section{Discussion}

The Coll plasmid was known to be generally stable in S. typhimurium (Barker, 1980) and was found to be rarely lost from cultures of $E$. coli to which it had been transferred. The $a b i$ gene, determining the character of abortive infection, is probably located on the ColI plasmid carried by strains of S. typhimurium (Yousuf et al., 1987), as it is on Collb-P9 also (Boulnois, 1981; Pinkerton et al., 1981). In this study, the characters Uvr, conferring enhanced resistance to UV-irradiation, and $\mathrm{Abi}$ were found in association with both ColIa and ColIb plasmids. They were frequently present together in that 88 of them were $\mathrm{Abi}^{+} \mathrm{Uvr}^{+}$and 62 $\mathrm{Abi}^{-} \mathrm{Uvr}^{-}$, whereas five were $\mathrm{Abi}^{+} \mathrm{Uvr}^{-}$and five $\mathrm{Abi}^{-} \mathrm{Uvr}^{+}$(table I). The Abi character or the Uvr character was occasionally not expressed by a plasmid previously found to be $\mathrm{Abi}^{+}$or that was thought to be $\mathrm{Uvr}^{+}$from the evidence of similar plasmids found in other strains of the same PT/BT group, e.g., strains of S. typhimurium of PT/BT 143/ 17a. Thus, each character may be lost independently. Plasmids were not analysed to determine whether phenotypic loss resulted from excision of the gene or from a mutation leading to the presence of a non-functional gene. Again, cultures that did not produce colicin were not examined for the $\mathrm{Abi}^{+}$ and $\mathrm{Uvr}^{+}$phenotypes although one conjugative plasmid (pRES-K317 found in E. coli strain K317) has been described (Males and Stocker, 1980) that was phage-restricting and conferred protection to UV-irradiation, but did not code for colicin production.

ColI plasmids derived from cultures of the same phage type and biotype isolated from sources that appeared related were usually of the same Abi/Uvr pattern; e.g., six Collb ${ }^{+}$isolates of $S$. typhimurium PT/BT $135 / 25 \mathrm{~h}$ from a localised outbreak in Edinburgh were $\mathrm{Abi}^{-} \mathrm{Uvr}^{-}$and five ColIb ${ }^{+}$ isolates of $S$. typhimurium PT/BT 141/1f were $\mathrm{Abi}^{+}$ $\mathrm{Uvr}^{+}$(table I).

The colicin type, Abi and Uvr characters of ColI plasmids carried by cultures of the same phage type and biotype from apparently unrelated sources were, in some instances, the same and suggested a possible epidemiological connection between the outbreaks, whereas among other groups of cultures the plasmids varied in one or more characters indicating that separate outbreaks were probably caused by different lines of infecting bacteria. Thus, 16 cultures of $S$. typhimurium of PT/BT $56 / 17 \mathrm{~g}$ carried ColI plasmids with the following combinations of characters: ColIa $\mathrm{Abi}^{+} \mathrm{Uvr}^{+}$, ColIa $\mathrm{Abi}^{-}$ $\mathrm{Uvr}^{-}$, ColIb Abi ${ }^{+} \mathrm{Uvr}^{+}$, Collb $\mathrm{Abi}^{-} \mathrm{Uvr}^{-}$(table I). The number of different plasmid types carried by the infecting strains suggested that the several outbreaks had originated from diverse sources.

The cultures of S. typhimurium of PT 141 (551 strains) isolated in Scotland from 1972 to 1977 were of one of three distinct clones of BT $1 \mathrm{f}, 9 \mathrm{f}$ and $31 \mathrm{bd}$ (Barker and Old, 1979). Colicinogenic strains of 
types If ColIa (1 strain), if ColIb (5), 9f ColIa (3) and $9 \mathrm{f} \mathrm{ColIb}(62)$ were isolated and 69 cultures were available for further examination. Abortive infection and sensitivity to UV differentiated the ColIa and ColIb plasmids carried by strains of biotype $9 \mathrm{f}$ into six subtypes (table I). Correlation of subtype character with epidemiological information considerably extended the degree of precision in tracing the likely route of spread of epidemic strains of $S$. typhimurium of PT/BT 141/9f (table II).

Early colicinogenic strains among the 110 isolates from human and other sources in Edinburgh in Aug. 1972 included 37 strains that were ColIb Abi ${ }^{-}$ $\mathrm{Uvr}^{-}$and nine strains isolated from human, bovine and milk sources associated with an outbreak in 1973 at Farm 7, Midlothian that were also ColIb $\mathrm{Abi}^{-} \mathrm{Uvr}^{-}$. Later isolates did not carry Collb plasmids with this Abi/Uvr pattern. From Jan. 1973 to Dec. 1977 strains of type 141/9f caused many infections in cattle and cases of human infection. The Coll types found were: ColIa $\mathrm{Abi}^{+}$ $\mathrm{Uvr}^{+}$(Penicuik Farm 4); ColIa $\mathrm{Abi}^{-} \mathrm{Uvr}^{+}$ (Lanarkshire Farm 21); Colla $\mathrm{Abi}^{-} \mathrm{Uvr}^{-}$(Glasgow); ColIb $\mathrm{Abi}^{+} \mathrm{Uvr}^{+}$(Edinburgh, Midlothian Farms 10 and 16, Wigtownshire Farm 12, and Glasgow); and ColIb $\mathrm{Abi}^{+} \mathrm{Uvr}^{-}$(Wishaw Farm 6, Midlothian Farm 10, Wigtownshire Farm 14) (table II). Thus, a source connected with the Edinburgh outbreak probably carried infection to Farm 7 where all victims were infected with $S$. typhimurium carrying an $\mathrm{Abi}^{-} \mathrm{Uvr}^{-} \mathrm{ColIb}$ plasmid, and no person or animal from Farm 7 was the source of a subsequent outbreak. Related sources in these subsequent outbreaks yielded isolates of mixed colicin types, i.e., $\mathrm{Col}^{-}$and $\mathrm{Col}^{+}$and infection probably originated with a non-colicinogenic line of PT/BT 141/9f that acquired a Col plasmid from other enteric organisms resident in the host (Barker 1980).

Most of the 419 cultures of $S$. agona examined by Barker et al. (1982) were of biotype 1a and colicinogeny was generally rare in that serotype. A rhamnose non-fermenting mutant line of biotype $5 \mathrm{a}$ and colicin type Ib, however, became established in Zaire in 1979 at a time when other patients in that area were excreting $\mathrm{ColIb}^{+}$strains of biotype 1a. The $\mathrm{Rha}^{-}$strains also differed from the $\mathrm{Rha}^{+}$ strains in phage type (table III). The ColIb plasmids carried by isolates of biotype la were of the types $\mathrm{Abi}^{+} \mathrm{Uvr}^{+}$and $\mathrm{Abi}^{-} \mathrm{Uvr}^{+}$, whilst those carried by the 20 isolates of biotype $5 \mathrm{a}$ were $\mathrm{Abi}^{+} \mathrm{Uvr}^{+}$. Thus, the presence of a plasmid of similar colicin type and Abi/Uvr pattern in isolates of both biotypes provided further indication that, although of different phage types, the rhamnose non-fermenting line probably arose from an ancestral bacterium of biotype la, as suggested before (Barker et al., 1982).

In conclusion, the presence of the marker characters Abi and Uvr carried by some ColIa and

Table II. Abortive infection (Abi) and sensitivity to ultraviolet irradiation (Uvr) associated with ColI plasmids in $S$. typhimurium strains of PT/BT 141/9f from outbreaks in Scotland 1972-1977

\begin{tabular}{|c|c|c|c|c|c|c|c|c|}
\hline \multirow[b]{2}{*}{ Year } & \multirow[b]{2}{*}{ Place of outbreak* } & \multicolumn{2}{|c|}{$\begin{array}{l}\text { Number of } \\
\text { isolates }\end{array}$} & \multirow[b]{2}{*}{ Col type } & \multicolumn{4}{|c|}{ Number with reaction pattern } \\
\hline & & All & $\mathrm{Col}^{+}$ & & $\begin{array}{l}\mathrm{Abi}^{+} \\
\mathrm{Uvr}^{+}\end{array}$ & $\begin{array}{l}\mathrm{Abi}^{+} \\
\mathrm{Uvr}^{-}\end{array}$ & $\begin{array}{l}\mathrm{Abi}^{-} \\
\mathrm{Uvr}^{+}\end{array}$ & $\begin{array}{l}\mathrm{Abi}^{-} \\
\mathrm{Uvr}^{-}\end{array}$ \\
\hline 1972 & $\begin{array}{l}\text { Edinburgh restaurant } \\
\text { Edinburgh (man) }\end{array}$ & $\begin{array}{l}53 \\
57\end{array}$ & $\begin{array}{r}5 \\
32\end{array}$ & $\begin{array}{l}\mathrm{Ib} \\
\mathrm{Ib}\end{array}$ & $\begin{array}{l}0 \\
0\end{array}$ & $\begin{array}{l}0 \\
0\end{array}$ & $\begin{array}{l}0 \\
0\end{array}$ & $\begin{array}{r}5 \\
32\end{array}$ \\
\hline $1972-73$ & Penicuik Farms 4, 5 & 16 & 1 & Ia & 1 & 0 & 0 & 0 \\
\hline 1973 & $\begin{array}{l}\text { Wishaw Farm } 6 \\
\text { Midlothian Farm } 7 \\
\text { Edinburgh (man) }\end{array}$ & $\begin{array}{r}3 \\
9 \\
20\end{array}$ & $\begin{array}{l}1 \\
9 \\
4\end{array}$ & $\begin{array}{l}\mathrm{Ib} \\
\mathrm{Ib} \\
\mathrm{Ib}\end{array}$ & $\begin{array}{l}0 \\
0 \\
4\end{array}$ & $\begin{array}{l}1 \\
0 \\
0\end{array}$ & $\begin{array}{l}0 \\
0 \\
0\end{array}$ & $\begin{array}{l}0 \\
9 \\
0\end{array}$ \\
\hline $\begin{array}{l}1973-75 \\
1973-76\end{array}$ & $\begin{array}{l}\text { Midlothian Farm } 10 \\
\text { Wigtownshire Farm } 12\end{array}$ & $\begin{array}{l}31 \\
50\end{array}$ & $\begin{array}{l}4 \\
3\end{array}$ & $\begin{array}{l}\mathrm{Ib} \\
\mathrm{Ib}\end{array}$ & $\begin{array}{l}2 \\
3\end{array}$ & $\begin{array}{l}2 \\
0\end{array}$ & $\begin{array}{l}0 \\
0\end{array}$ & $\begin{array}{l}0 \\
0\end{array}$ \\
\hline 1974 & $\begin{array}{l}\text { Wigtownshire Farm } 14 \\
\text { Midlothian Farm } 16 \\
\text { Lanarkshire Farm } 21\end{array}$ & $\begin{array}{l}3 \\
1 \\
2\end{array}$ & $\begin{array}{l}1 \\
1 \\
1\end{array}$ & $\begin{array}{l}\mathrm{Ib} \\
\mathrm{Ib} \\
\mathrm{Ia}\end{array}$ & $\begin{array}{l}0 \\
1 \\
0\end{array}$ & $\begin{array}{l}1 \\
0 \\
0\end{array}$ & $\begin{array}{l}0 \\
0 \\
1\end{array}$ & $\begin{array}{l}0 \\
0 \\
0\end{array}$ \\
\hline 1975 & Glasgow (man) & 22 & 1 & $\mathrm{Ib}$ & 1 & 0 & 0 & 0 \\
\hline 1976 & Glasgow (man) & 30 & 1 & Ia & 0 & 0 & 0 & 1 \\
\hline
\end{tabular}

* For further details see Barker and Old (1979). 
Table III. Characters of S. agona strains isolated in Zaire in 1979 and 1980

\begin{tabular}{ccccc}
$\begin{array}{c}\text { Year of } \\
\text { isolation }\end{array}$ & $\begin{array}{c}\text { Number of } \\
\text { isolates }\end{array}$ & $\begin{array}{c}\text { Phage } \\
\text { type }\end{array}$ & Biotype & $\begin{array}{c}\text { Plasmid } \\
\text { type }\end{array}$ \\
\hline 1979 & 4 & V & $1 \mathrm{a}$ & $\mathrm{Collb} \mathrm{Abi}^{+} \mathrm{Uvr}^{+}$ \\
1979 & 2 & $\mathrm{~V}$ & $1 \mathrm{a}$ & $\mathrm{ColIb} \mathrm{Abi}^{-} \mathrm{Uvr}^{+}$ \\
1979 & 2 & $\mathrm{I}$ & $1 \mathrm{a}$ & ${\mathrm{ColIb} \mathrm{Abi}^{-} \mathrm{Uvr}^{+}}^{+}$ \\
1980 & 7 & $\mathrm{XV}$ & $1 \mathrm{a}$ & $\mathrm{Col}^{-}$ \\
1979 & 6 & $\mathrm{XVI}$ & $5 \mathrm{a}$ & $\mathrm{ColIb} \mathrm{Abi}^{+} \mathrm{Uvr}^{+}$ \\
1979 & 1 & $\mathrm{NT}$ & $5 \mathrm{a}$ & $\mathrm{ColIb} \mathrm{Abi}^{+} \mathrm{Uvr}^{+}$ \\
1980 & 13 & $\mathrm{XVI}$ & $5 \mathrm{a}$ & $\mathrm{ColIb} \mathrm{Abi}^{+} \mathrm{Uvr}^{+}$ \\
1980 & 1 & $\mathrm{XVI}$ & $5 \mathrm{a}$ & $\mathrm{Col}^{-}$ \\
\hline
\end{tabular}

NT = non-typable.

Collb plasmids greatly extended the value of plasmid typing of otherwise identical strains of Salmonella. Coll plasmids of mol. wt c. $61.5 \times 10^{6}$ are relatively large and may well carry genes for other characters that may be used to differentiate

\section{REFERENCES}

Abbott J D, Shannon R 1958 A method for typing Shigella sonnei using colicine production as a marker. Journal of Clinical Pathology $11: 71-77$.

Anderson E S 1975 Viability of, and transfer of a plasmid from, E. coli $\mathrm{K} 12$ in the human intestine. Nature 255:502-504.

Anderson E S, Ward L R, De Saxe M J, Old D C, Barker R M, Duguid J P 1978 Correlation of phage type, biotype and source in strains of Salmonella typhimurium. Journal of Hygiene 81 : 203-217.

Barker R M 1980 Colicinogeny in Salmonella typhimurium. Journal of General Microbiology 120:21-26.

Barker R M $1986 a$ Tracing Salmonella typhimurium infections. Journal of Hygiene $96: 1-4$.

Barker R M 1986b Epidemic strains of Salmonella agona differentiated by phage restriction and u.v.-protection markers on Collb plasmids. Letters in Applied Microbiology 3:101-104.

Barker R M, Old D C 1979 Biotyping and colicine typing of Salmonella typhimurium strains of phage type 141 isolated in Scotland. Journal of Medical Microbiology 12:265-276.

Barker R M, Old D C, Sharp J C M 1980 Phage type/biotype groups of Salmonella typhimurium in Scotland 1974-6: variation during spread of epidemic clones. Journal of Hygiene 84: 115-125.

Barker R M, Old D C, Tyc Z 1982 Differential typing of Salmonella agona: type divergence in a new serotype. Journal of Hygiene 88:413-423. the plasmids and monitor their spread in host bacteria.

This work was supported by a grant from Tayside Health Board.

Boulnois G J 1981 Colicin Ib does not cause plasmid-promoted abortive phage infection of Escherichia coli K12. Molecular and General Genetics 182: 508-510.

Howarth S 1965 Resistance to the bactericidal effect of ultraviolet radiation conferred on Enterobacteria by the colicine factor ColI. Journal of General Microbiology 40:43-55.

Males B M, Stocker B A D 1980 Escherichia coli K317, formerly used to define colicin group E2, produces colicin E7, is immune to colicin E2, and carries a bacteriophagerestricting conjugative plasmid. Journal of Bacteriology 144: 524-531.

Ozeki H, Stocker B A D, Smith S M 1962 Transmission of colicinogeny between strains of Salmonella typhimurium grown together. Journal of General Microbiology 28:671687.

Pinkerton T, Muzyczka N, Walia S, Dunn G, Rose K, Duckworth D 1981 Bacteriophage T5 growth in Escherichia coli containing cloned Pst I fragments of the colicin Ib plasmid. Gene 16:89-96.

Stocker B A D 1966 Heterogeneity of I colicines and I colicine factors. Heredity 21 : 166.

Strobel M, Nomura M 1966 Restriction of bacteriophage BF23 by a colicine (ColI-P9) factor. Virology 28:763-765.

Yousuf A A, Ling T K W, Barker R M 1987 Differentiation of Coll plasmids by ability to cause abortive infection of bacteriophages BF23 and T5. Letters in Applied Microbiology 5:33-36. 